Brit. F. vener. Dis. (1967), 43, 275.

\title{
VENEREAL DISEASE IN AN ELITE GROUP (UNIVERSITY STUDENTS) IN EAST AFRICA*
}

\author{
BY \\ O. P. ARYA AND F. J. BENNETT \\ College Health Service and Department of Preventive Medicine, Makerere Medical School, \\ University of East Africa
}

Venereal disease especially in younger people is becoming an increasingly serious problem in many parts of the world (British Medical Association, 1964; King, 1965). This trend, so well documented in developed countries, has received less attention in developing countries. What little has been published has been largely drawn from the large hospitals serving the general population in the big towns (Kibukamusoke, 1965). Bennett (1964), however, drew attention to the problem of gonorrhoea in rural Uganda and also observed that in East Africa higher social class is not always associated with a decreased incidence of gonorrhoea (Bennett, 1962).

This paper attempts to bring a facet of this problem in developing countries into focus by analysing a neglected source of material, namely College Health Service records. Catterall (1962), who called attention to the problem in Leeds, discovered that no factual data had been published on the incidence of venereal disease amongst students in the previous 12 years. Morton (1966) has since made a retrospective study of students in Sheffield and has found that the incidence rate for venereal disease in students had risen from 2.9 per 1,000 in 1961 to 5.5 per 1,000 in 1965 . He also calculated separate rates for overseas students and showed that they had also increased, being five times greater than the rates for British students. Besides these papers we have only one paper on venereal disease in the Report of the World University Student Conference of Experts in Student Health in

* Received for publication May 16, 1967.
Asia (Frohlich, 1962) and mimeographed reports from some college health services in Africa.

This paucity of data is partly due to reluctance to publish material which might be interpreted as an indictment of the University concerned. This leads each institution to think that its problems are unique, resulting in an absence of documented control measures.

It seems certain that venereal disease is a major problem in many universities in Africa and it is hoped that this description of the epidemiology and pattern of venereal disease in one college will encourage the publication of data from other centres.

\section{Method}

During 1966 the two doctors working in the College Health Service had many discussions to ensure uniform recording and investigation and management of all cases of venereal disease. This free health service has the confidence of the students and it is likely that it treats the great majority of cases and that only a small percentage go to private practitioners. (This is in contrast to many other universities where the majority of cases of venereal disease would not be seen by the College Health Service.) The records of all male cases of venereal disease in 1966 were analysed with respect to the following factors: ethnic origin, age, marital status, residence, year of entrance to College, faculty, frequency of venereal disease, data concerning illness, and clinical picture. Female patients were excluded because of the greater difficulties of definite diagnosis. Numbers at risk were obtained from the College nominal roll of students (predominantly undergraduates with only a small minority of postgraduate students, mostly in the Faculty of Education). 


\section{Frequency}

\section{Results}

Venereal disease is one of the major health problems of college life. In 1966, out of a total of 8,145 male attendances, 1,906 (23 per cent.) were related to venereal disease. 340 male students out of approximately 1,200 at risk suffered 476 attacks of venereally-transmitted disease (Table I). An additional 59 were exposed to risk and actually came for examination but were found not to have venereal disease-there were probably very many more in this category who never reported.

Asians have the lowest incidence, students from African states outside East Africa the highest, and the next highest are other Bantu-speaking men from Uganda and Ganda.

TABLE I

ETHNIC AND NATIONAL ORIGIN

\begin{tabular}{|c|c|c|c|c|}
\hline Country & Ethnic Group & $\begin{array}{l}\text { Number } \\
\text { of V.D. } \\
\text { Patients }\end{array}$ & $\begin{array}{c}\text { Number } \\
\text { at Risk }\end{array}$ & $\begin{array}{c}\text { Rate } \\
\text { per } \\
\text { cent. }\end{array}$ \\
\hline \multirow[t]{3}{*}{ Uganda } & \multirow{3}{*}{$\begin{array}{l}\text { Ganda } \\
\text { Other Bantu-speaking } \\
\text { Tribes } \\
\text { Nilotic, Nilohamitic, and } \\
\text { Sudanic } \\
\text { Asian }\end{array}$} & 69 & & $35 \cdot 9$ \\
\hline & & 93 & 244 & $38 \cdot 1$ \\
\hline & & $\begin{array}{r}44 \\
2\end{array}$ & $\begin{array}{r}157 \\
59\end{array}$ & $\begin{array}{r}28 \cdot 0 \\
3 \cdot 4\end{array}$ \\
\hline Kenya & $\begin{array}{l}\text { African-All Tribes } \\
\text { Asian }\end{array}$ & $\begin{array}{r}38 \\
2\end{array}$ & $\begin{array}{r}191 \\
55\end{array}$ & $\begin{array}{r}19 \cdot 9 \\
3.6\end{array}$ \\
\hline Tanzania & $\begin{array}{l}\text { African-All Tribes } \\
\text { Asian }\end{array}$ & $\begin{array}{r}44 \\
3\end{array}$ & $\begin{array}{r}129 \\
43\end{array}$ & $\begin{array}{r}34 \cdot 1 \\
7 \cdot 0\end{array}$ \\
\hline \multicolumn{2}{|c|}{ Other African States } & 29 & 61 & $47 \cdot 5$ \\
\hline \multicolumn{2}{|c|}{ U.K. and U.S.A. } & 16 & 63 & $25 \cdot 4$ \\
\hline \multicolumn{2}{|c|}{ Total } & 340 & 1194 & $28 \cdot 5$ \\
\hline
\end{tabular}

Age Distribution (Table II)

The majority of College students are in the 21 to 25-year age group, which contributes most cases. Unfortunately it was not possible to obtain the number at risk in each age group.

Of the 340 students with venereal disease, 24 ( 7 per cent.) were married; twelve of these came from outside East Africa, and another eight had left their wives at a distant home. Sixteen were aged over 30 years. Approximately 8 per cent. of all students in the College are married.

TABLE II

AGE DISTRIBUTION

\begin{tabular}{c|c}
\hline Age Group (yrs) & No. of V.D. Patients \\
\hline Below 20 & 6 \\
$21-25$ & 234 \\
$26-30$ & 80 \\
Over 30 & 20 \\
\hline
\end{tabular}

\section{Place of Residence}

Almost all students were in residence in College and there was no striking difference in incidence between the different Halls.

\section{Year of Entry}

In the first half of the year, of 136 students who contracted venereal disease, 71 ( 52 per cent.) were in their first year. The freshmen enter the College in July and during the second 6 months of the year half the cases were newcomers. By the end of their first 6 months in the College, 23 per cent. of male freshmen had already contracted their first episode of venereal disease.

\section{Incidence in Various Faculties (Table III)}

The higher incidence in the second hals of the year is probably related to the intake of new students and the return of old students after a long vacation of 3 months. The high rate in the Faculty of Agriculture in the second half of 1966 was partly due to an increased intake of freshmen. In this Faculty, students spend more time at a teaching farm outside the College and many cases are seen during this period. The low rates in the Faculty of Medicine are especially striking, as this Faculty also had a greater intake than usual in 1966. Within the Faculty of Medicine most venereal disease is seen in the pre-clinical years. Very few medical students

TABLE III

FACULTY DISTRIBUTION

\begin{tabular}{|c|c|c|c|c|c|c|}
\hline \multirow{2}{*}{ Faculty } & \multicolumn{3}{|c|}{ January to June, 1966} & \multicolumn{3}{|c|}{ July to December, 1966} \\
\hline & No. of V.D. Patients & No. of Students & Rate per cent. & No. of V.D. Patients & No. of Students & Rate per cent. \\
\hline $\begin{array}{l}\text { Arts } \\
\text { Agriculture } \\
\text { Education } \\
\text { Fine Art } \\
\text { Medicine } \\
\text { Science } \\
\text { Library }\end{array}$ & $\begin{array}{r}59 \\
14 \\
20 \\
6 \\
19 \\
18 \\
0\end{array}$ & $\begin{array}{r}422 \\
86 \\
170 \\
35 \\
249 \\
161 \\
8\end{array}$ & $\begin{array}{r}13.9 \\
16.2 \\
11.7 \\
17.1 \\
7.6 \\
11.1 \\
0.0\end{array}$ & $\begin{array}{r}79 \\
31 \\
26 \\
7 \\
28 \\
33 \\
0\end{array}$ & $\begin{array}{r}417 \\
121 \\
184 \\
44 \\
295 \\
177 \\
19\end{array}$ & $\begin{array}{r}18 \cdot 9 \\
25 \cdot 6 \\
14 \cdot 1 \\
15 \cdot 9 \\
9 \cdot 4 \\
18 \cdot 6 \\
0 \cdot 0\end{array}$ \\
\hline Total & 136 & 1,131 & & 204 & 1257 & \\
\hline $\begin{array}{l}\text { Mean Rate per cent. } \\
\text { All Faculties }\end{array}$ & & & $12 \cdot 02$ & & & $16 \cdot 2$ \\
\hline
\end{tabular}


in their clinical years came for treatment. Probably this is due to their knowing more about the disease, more being married, more receiving treatment from house physicians in the wards where they are working, or perhaps in some cases treating themselves.

\section{Frequency of Attacks}

Table IV shows the frequency of attacks of venereal disease in the 340 students studied and also the frequency distribution of attacks since entry to College.

In 1966 the 340 individuals who suffered from venereal disease had 476 attacks. When traced back through the records of previous years these 340 individuals had to date had 677 episodes of venereal disease since entry to College.

First year students also form the majority of repeaters-out of 104 with repeated attacks in 1966, 58 were in their first year. Of those having more than two attacks, up to two-thirds were freshmen.

TABLE IV

FREQUENCY OF ATTACKS

\begin{tabular}{l|c|c}
\hline \multirow{2}{*}{$\begin{array}{l}\text { No. of } \\
\text { Attacks } \\
\text { of V.D. }\end{array}$} & \multicolumn{2}{|c}{ No. having V.D. } \\
\cline { 2 - 3 } & January to December, 1966 & Since Entry to College \\
\hline 1 & 236 & 172 \\
2 & 79 & 81 \\
3 & 18 & 46 \\
4 & 7 & 18 \\
5 & - & 13 \\
6 & - & 5 \\
7 & - & 2 \\
8 & - & 3 \\
\hline
\end{tabular}

\section{Seasonal Incidence (Table V)}

Many of the attacks reported in January were due to exposure to risk during the Christmas vacation, some cases having received inadequate treatment outside the College. Similarly, in July, many had contracted the disease in the latter half of the June vacation. The peaks in January, July, and October coincide with the commencement of new terms. There are fewer in February and March because these are examination periods when students are occupied most of the time. April, May, and June are long vacation months when very few students remain in College
Clinical Pattern of Disease (Table VI)

The number of clinical diagnoses (533) exceeds the number of episodes (476) because there were some multiple infections, and the number of episodes exceeds the number of patients (340) because of re-infections.

TABLE VI

CLINICAL PATTERN OF DISEASE

\begin{tabular}{|c|c|}
\hline Diagnosis & No. of Diagnoses \\
\hline Gonococcal Urethritis & 224 \\
\hline Non-gonococcal Urethritis & $\begin{array}{l}191 \text { (172 non-specific, } 18 \text { Tricho- } \\
\text { monas vaginalis urethritis, } \\
1 \text { Bacterial) }\end{array}$ \\
\hline Balanitis/Balanoposthitis & 32 \\
\hline Syphilis & 29 (15 early, 14 late) \\
\hline Chancroid & 11 \\
\hline Lymphogranuloma Venereum & 2 \\
\hline Genital Herpes & 5 \\
\hline Pediculosis pubis & 4 \\
\hline $\begin{array}{l}\text { Other (including Prostatitis (13) } \\
\text { and Epididymo-orchitis (4)) }\end{array}$ & 35 \\
\hline
\end{tabular}

All patients presenting with urethral discharge had smears taken and most also had cultures using Stuart's transport medium. Non-specific urethritis was diagnosed when smear and culture were negative and there was no response to penicillin. However, 25 cases with negative smears (of which twelve had cultures which were negative) did respond to penicillin and remained symptom-free on follow-up. In several cases of non-gonococcal urethritis a variety of organisms (e.g. Staphylococcus albus, Streptococcus viridans, B. proteus) was cultured, but in only one case due to coliforms was this considered pathogenic. In addition to the eighteen proved cases of Trichomonas vaginalis urethritis, there were nine cases of non-specific urethritis which responded ultimately to a 7-day course of 'Flagyl' (metronidazole) although no trichomonads had been isolated. It is probable that some of these were cases of double infection. Facilities for the isolation and identification of Trichomonas vaginalis were not ideal and it is likely that the true incidence is higher than the figures suggest.

Of the thirteen cases of prostatitis, culture of prostatic fluid yielded Staphylococcus pyogenes in one, Streptococcus viridans in one, and B. proteus in two.

TABLE V

SEASON OF ILLNESS

\begin{tabular}{l|c|c|c|c|c|c|c|c|c|c|c|c|}
\hline Month & Jan. & Feb. & Mar. & Apr. & May & Jun. & Jul. & Aug. & Sep. & Oct. & Nov. & Dec. \\
\hline No. of Cases & 67 & 26 & 31 & 17 & 17 & 7 & 71 & 51 & 55 & 56 & 40 & 38 \\
\hline
\end{tabular}




\section{Relapse versus Re-infection}

A history of re-exposure is denied initially in many cases of recurrence of symptoms. However, with tactful and persistent questioning, re-infection can usually be distinguished from relapse. Out of a total of 240 re-infections, at least 109 occurred within 3 months of the previous infection. Of these 109 , three were re-infected within one week of the previous infection, 41 within one month, and 65 within 3 months. True relapses were rare.

\section{Fear of Venereal Disease}

During 1966, 79 students reported for examination fearing that they had contracted venereal disease, but 59 of them did not in fact contract any disease that year. Some students came on more than one occasion. Kikuyu and Asian students appeared to develop this anxiety more frequently than other ethnic groups.

\section{Anxiety following Venereal Disease}

25 cases continued to have symptoms and anxiety even after cure. The symptoms described were often vague, but led to further investigations and continued treatment.

Post-venereal disease anxiety and fear of venereal disease adds a considerable load of consultations to the College clinic.

\section{Discussion}

It is apparent from this analysis that venereal disease presents a very special problem in College students in East Africa and it ranks with psychoneuroses and upper respiratory infections in causing a great deal of the morbidity seen in the health service. This is an ironical situation, since one would imagine that a disease considered to be preventable should have a lower frequency in the best educated élite group. These findings are in contrast to those of the committee of the British Medical Assocation (1964), which found that venereal disease was not common in students as compared with other young people. Perhaps a reason for this difference is that there are as yet few women students in universities in Africa so that the sexual partners of male students must be drawn from outside the university-often from a lower social group or from prostitutes.

The lower incidence in Asian students must be related to sociocultural factors which deserve further study.

The tribal incidence indicates that Bantu-speaking tribes from Uganda have the highest incidence of all the Ugandans ( $38 \cdot 1$ per cent.) possibly because of a greater use of the local night clubs and prostitutes.
Nilotic and other language groups usually have more permanent female friends and there are fewer prostitutes from these ethnic groups. Students from elsewhere in Africa behave as immigrants to the town and have the highest risk of any immigrant group, being away from wives and behaviourmoderating relatives. Very few of the older students are able to have their wives with them, but venereal disease is not so much a problem in this age group as in the unmarried freshmen. The casting off of the restraints of home and school, the new freedom to go to night clubs, the glamour and sophistication of the city prostitutes, and the social immaturity of the first year student all contribute to the higher incidence. The individuals who repeatedly contract venereal disease must in addition have personality factors associated with promiscuity. Stress at the time of examinations accounts for some students becoming infected in February and March, and increased leisure and relaxation after examinations also produces some cases.

It is at least a consolation that treatment is usually sought early-sometimes in the middle of the night as an emergency. The cases of gonorrhoea responded to high and adequately sustained dosage of penicillin. Non-specific urethritis usually responded best to tetracycline but some cases responded to combined streptomycin and long-acting sulphonamide, the dosages employed being those recommended by King and Nicol (1964). The trichomonas infections responded to metronidazole. The other venereal diseases responded to the standard treatment. This series gives a different pattern from that described by Kibukamusoke (1965) who drew his patients from Mulago Hospital Out-patient Department. The incidence of non-specific urethritis is much higher in College students-it is not clear if this is due to our use of strictly bacteriological criteria for diagnosing gonorrhoea or if in fact a different population is being studied; perhaps a population with more exposure to penicillin, and consequently greater selection of organisms producing non-specific urethritis.

Prevention of venereal disease in university students is no easier than preventing the common cold-in the former sexual intercourse and in the latter social intercourse being the causative behaviour factor. Neither can in reality be stopped, but greater discretion can be used. Sex instruction and specific education about venereal disease in the College appear to induce little change and probably very little can be achieved by starting only with this one small section of the community. The whole pattern of sexual behaviour in the society of the town in which the university is situated would have to be 
altered first to affect the incidence. As Leob (1960) has suggested, a modern health education programme is required which will fit the changing sexual mores of to-day rather than reliance on traditional and now unrealistic moral principles.

\section{Summary}

Venereal disease is an important problem in young people and data on College students is scarce. In a College health service in East Africa, venereal disease accounted for 23 per cent. of all attendances, and almost one in four men at risk contracted the disease in one year. Incidence rates varied in different ethnic groups-Asians having very low rates. Rates also differed in different faculties, that for Medicine being the lowest.

Approximately half the cases occurred in students in their first year in College. Of the many individuals who had repeated attacks again most were freshmen. The peaks of incidence occurred at the commencement of term. Gonococcal urethritis and non-specific urethritis were the most common conditions. On careful history taking, re-infection proved to be the usual cause of recurrence of symptoms rather than relapse. Fear of venereal disease and psychoneurosis following disease added a considerable load of work to the College clinic. Methods of treatment and control are briefly discussed.

\section{REFERENCES}

Bennett, F. J. (1962). E. Afr. med. F., 39, 332. (1964). Ibid., 41, 163.

British Medical Association (1964). "Venereal Disease and Young People."

Catterall, R. D. (1962). "The Proceedings of the British Student Health Assocation", p. 34.
Frohlich, W. (1962). "Student Health in Asia" (Report of the World University Service Asian Conference of Experts on Student Health, Paredeniya, Ceylon), p. 93.

Kibukamusoke, J. W. (1965). Trans. roy. Soc. trop. Med. Hyg., 59, 642.

King, A. J. (1965). Wld Hlth Org. Chron., 19, 144. and Nicol, C. S. (1964). "Venereal Diseases". Cassell, London.

Loeb, M. B. (1960). Brit. F. vener. Dis., 36, 191.

Morton, R. S. (1966). Ibid., 42, 280.

Les maladies vénériennes chez une élite composée d'étudiants à une Université en Afrique Orientale. RÉsumé

Les maladies vénériennes forment un problème important chez les jeunes et les renseignements au sujet des étudiants sont rares. Dans un service de Santé pour les étudiants en Afrique Orientale les maladies vénériennes s'élevaient à 23 pour cent de toutes les visites au dispensaire et presqu'un étudiant sur quatre qui s'étaient exposés avait contracté la maladie dans l'espace d'une année. Les taux d'incidence variaient d'après les différents groupes ethniques-les Asiatiques ayant le taux le plus bas. Les taux variaient aussi chez les différentes facultés, celle de la Médicine étant le plus bas.

A peu près la moitié des cas a été vue chez les étudiants de première année à l'Université. Des nombreux étudiants qui avaient eu des attaques répétées beaucoup étaient des étudiants de première année. Les sommets du graphique de l'incidence des case avaient eu lieu au début du terme. L'urétrite blennorragique et l'urétrite non-spécifique avaient été les plus fréquentes. Un historique méticuleux a prouvé qu'une ré-infection plutôt qu'une rechute avait été la cause usuelle du retour des symptômes. La peur des maladies vénériennes et la psychonévrose qui les accompagne ont beaucoup augumenté le travail du dispensaire attaché à l'Université. Les méthodes de traitement et les mesures prises pour la réduction des cas sont brièvement discutées. 